\title{
FERTILIZERS AND LIME FOR NORTH AUCKLAND SOILS
}

\author{
C. DURIng \\ Scientist, Ruakura Soil Research Station, Hamilton
}

NORTH AUCKLAND is covered by a large variety of soils. These have developed on sandstones, mudstones, andesitic rocks, basalt, volcanic ash and mixtures of these materials. Further, on each type of parent material, time and environment have combined to create a range or "suite" of soils. The term and concept of soil "suites" was developed by Taylor (1952), formerly Director of the New Zealand Soil Bureau. Dr Taylor's system of grouping these soils has been of very great help in planning field and laboratory experiments. Table 1 outlines a simplified model of a soil suite developed on sandstone.

Natural fertility is highest on the A type soils, very much lower on the $B$ and $C$ type soils and very low on the $D$ and $E$ soils. The last two ( $D$ and $E$ ) and part of the $C$ soils used to be dug for kauri gum. Hence they are known as gumland soils.

TABLE 1: AN OUTLINE OF A SOIL SUITE DEVELOPED ON SANDSTONE

\begin{tabular}{|c|c|c|c|}
\hline Class & $\begin{array}{l}\text { Contour } \\
\text { of Land }\end{array}$ & $\begin{array}{l}\text { Colour of } \\
\text { Upper Subsoil }\end{array}$ & Comments \\
\hline $\bar{A}$ & Very steep & Light brown & $\begin{array}{l}\text { Clay loams, a few stones not far } \\
\text { below surface. }\end{array}$ \\
\hline & $\begin{array}{l}\text { Moderately steep } \\
\text { to rolling }\end{array}$ & $\begin{array}{l}\text { Yellow-brown to } \\
\text { vivid red-brown }\end{array}$ & $\begin{array}{l}\text { Clays or clay loams often finely } \\
\text { granular, }\end{array}$ \\
\hline & $\begin{array}{l}\text { Moderately steep } \\
\text { to undulating, } \\
\text { also hill tops }\end{array}$ & $\begin{array}{l}\text { Grey-brown or } \\
\text { yellow-grey }\end{array}$ & $\begin{array}{l}\text { Lower subsoil usually mottled } \\
\text { clay or sandy clay. }\end{array}$ \\
\hline $\mathrm{D}$ & $\begin{array}{l}\text { Undulating and } \\
\text { hill tops }\end{array}$ & $\begin{array}{l}\text { Grcy and light } \\
\text { yellow-grey }\end{array}$ & $\begin{array}{l}\text { Sandy loam on top, mottled clay } \\
\text { below. }\end{array}$ \\
\hline $\mathrm{E}$ & $\begin{array}{l}\text { Undulating to } \\
\text { flat }\end{array}$ & Grey & $\begin{array}{l}\text { Sandy loam often with white- } \\
\text { grey or dark brown pan } 8 \text { to } \\
12 \text { in. below surface. }\end{array}$ \\
\hline
\end{tabular}


Soils in suites derived from parent materials other than sandstone do not always exhibit marked differences in colour. On mudstone, shades of the $A$ to $C$ soils are generally paler than on corresponding soils derived from sandstone.

In the suites derived from andesite (semi-volcanic soils) the sequences from A to D have mainly brown to greybrown upper subsoils. Vivid red-browns and browns are found in soils developed from basalt, grading to dull browns with ironstone nodules in the D-E types.

In all, there are about seven major soil suites in North Auckland and several minor ones. Soils in North Auckland can, therefore, be likened to a tree. The main branches are the parent material, the smaller branches the individual soil types developed in each material and finally the twigs are the soils on individual farms modified by topdressing and the grazing animal.

There are, of course, far too many twigs or even little branches on this tree of soils to make it practical to describe individual fertilizer treatments for them. Considerable simplification is needed. How this is achieved is shown by discussing individual fertilizer materials, lime and molybdenum.

\section{LIME, FERTILIZER AND MOLYBDENUM REQUiREMENTS}

Although a great deal of field and laboratory work has been carried out, there are still gaps in our knowledge. Yet reasonably precise recommendations on fertilizer and lime requirements can be given. The situation is aggravated, however, by the need to fit fertilizer recommendations to the amount of feed required on individual farms. In many cases, a problem arises owing to differences in seasonal growth patterns between high-producing and relatively lowproducing pasture. For instance, what is the value of a paspalum dominant pasture producing enough over the year to feed six sheep but virtually nothing in winter and early spring?

\section{MOI ,YBDENUM AND LTME}

Lime is beneficial on many soils and molybdenum deficiency is extremely widespread. It is said that molybdenum can replace lime and vice versa. While this statement is true on many soils, there are several exceptions. In North Auckland, from the practical point of view, it is best to consider molybdenum and lime as independent entities. 
Molybdenum should be used where it is needed, and the same applies to lime. Molybdenum is cheap and liming is much more costly. For this reason, the use of lime must be kept in step with the use of other costly materials such as phosphate and potash. The best results are obtained from a correct balance of fertilizers and lime. For reasons of economy, most farmers need to accept pastures which are slightly but clearly deficient in phosphate and potash growing on soils slightly more acid than optimum. Under these conditions, pastures can still yield 8,000 to $12,000 \mathrm{lb}$ dry matter (on land which can be cultivated) and can feed approximately 1 to $1 \frac{1 / 2}{2}$ dairy cows or 6 to 9 ewe equivalents per acre (Coop, 1965; J. B. Hutton, pers. comm.).

Land too steep for cultivation should still be capable of carrying 5 to 7 ewe equivalents per acre.

Table 2 shows approximate molybdenum requirements of pastures in North Auckland soils if this material is applied as sodium molybdate at $21 / 2$ to $5 \mathrm{oz}$ per acre.

Table 3 summarizes approximate lime requirements of pasture (modified by economic consideration).

On land to which an unknown quantity of lime has been applied previously, soil $\mathrm{pH}$ is a fairly useful indication of requirements. Soil $\mathrm{pH}$ should not be lower than $\mathrm{pH} 5.2$ and seldom needs to be higher than pH 5.8 ( 0 to 3 in. horizon).

TABLE 2: APPROXIMATE MOLYDENLJM REQUIREMENTS OF NORTH AUCKLAND SOILS

\begin{tabular}{|c|c|c|}
\hline Soils & $\begin{array}{l}\text { Interval of } \\
\text { Topdressing } \\
\quad \text { (years) }\end{array}$ & Comments \\
\hline $\begin{array}{l}\text { Sandstone } \\
\text { A to E } \\
\text { inclusive }\end{array}$ & $2-5$ & $\begin{array}{l}\text { On E (Wharekohe sandy loam) defi- } \\
\text { ciency may develop after a few years' } \\
\text { farming only. }\end{array}$ \\
\hline $\begin{array}{l}\text { Andesites, dolerites } \\
\text { (semi-volcanic } \begin{array}{l}\text { soils) } \\
\text { A-D }\end{array}\end{array}$ & s 2 & \\
\hline $\begin{array}{l}\text { Mudstone } \\
\text { C-E }\end{array}$ & $2-5$ & $\begin{array}{l}\text { On E deficiency may develop after a } \\
\text { few years' farming only. }\end{array}$ \\
\hline $\begin{array}{l}\text { Basalt } \\
\text { C-E }\end{array}$ & $4-5$ & \\
\hline $\begin{array}{l}\text { Windblown sand } \\
\text { D and E }\end{array}$ & $5-7$ & \\
\hline Limestone & $3-5$ & D and E type soils do not occur. \\
\hline
\end{tabular}


TABLE 3: APPROXIMATE INITIAL LIME REQUIREMENTS OF NORTH AUCKLAND PASTURES

According to Soil Group in Cwt/Acre

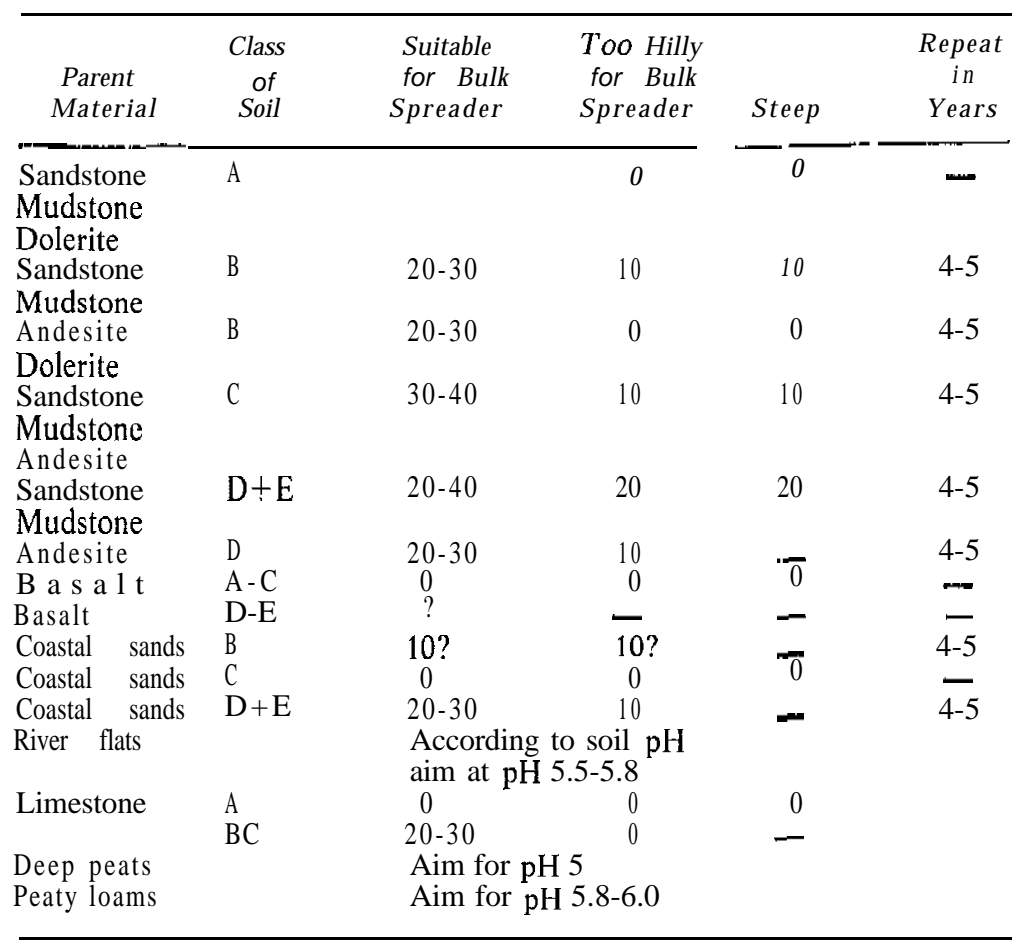

\section{SULPHUR}

Superphosphate contains $10 \%$ sulphur (as against $9 \%$ phosphorus) and hence is the major supplier of this element. On intensively-farmed land, some 5 to $7 \mathrm{lb}$ sulphur per acre may be carried away annually from the main grazing area and some of this is replaced by sulphur in rain (During, 1967). Therefore, if no sulphur is lost by leaching, or run-off, or by incorporation in organic matter, the longterm needs of sulphur to maintain pasture production are not large. One of the critical points is, of course, whether leaching or run-off of sulphur occur. Hogg (1965) has developed a laboratory leaching technique to test this point. His work has proved of great value to those who plan and carry out field experiments with sulphur. 
FERTILIZERS AND LIME

TABLE 4: APPROXIMATE SLJLPHUR REQUIREMENTS OF SOILS IN NORTH AUCKLAND

\begin{tabular}{|c|c|c|}
\hline $\begin{array}{l}\text { Parent } \\
\text { Muterial }\end{array}$ & $\begin{array}{l}\text { Sail } \\
\text { Class }\end{array}$ & $\begin{array}{l}\text { Comments Based on Laboratory and Fiedd } \\
\text { Trial Results }\end{array}$ \\
\hline $\begin{array}{l}\text { Sandstones } \\
\text { Mudstones }\end{array}$ & $\mathrm{A}+\mathrm{B}$ & $\begin{array}{l}\text { Sulphate not strongly held but little leaching: } \\
\text { small sulphur requirements. }\end{array}$ \\
\hline Sandstones & $\mathrm{C}+\mathrm{D}$ & Top 6 to 12 in. do not always retain sulphate; \\
\hline Mudstones & CDE & $\begin{array}{l}\text { it is likely that superphosphate applies enough } \\
\text { sulphur. Do not use sulphur-free phosphatic } \\
\text { fertilizers. }\end{array}$ \\
\hline Sandstone & $\mathrm{E}$ & $\begin{array}{l}\text { Good field evidence of rapid decline in avail- } \\
\text { ability of applied sulphate. Use sulphur-fortified } \\
\text { superphosphate. }\end{array}$ \\
\hline Limestone & A-C & $\begin{array}{l}\text { Weak field evidence but sulphur deficiency sus- } \\
\text { pected. Do not use sulphur-free phosphatic } \\
\text { fertilizers. }\end{array}$ \\
\hline Windblown sand & A-E & $\begin{array}{l}\text { Some sulphur responses obtained in field. Great } \\
\text { variability in sulphur retention. Probably no } \\
\text { need to use sulphur-fortified superphosphate } \\
\text { except possibly in some E soils. }\end{array}$ \\
\hline $\begin{array}{l}\text { Andesite, dolerite } \\
\text { Basalt }\end{array}$ & $\begin{array}{l}\text { A-D } \\
\text { A-E }\end{array}$ & $\begin{array}{l}\text { Soils retain sulphate; sulphur not a critical } \\
\text { fertilizer element unless rapid build-up of } \\
\text { organic sulphur occurs. }\end{array}$ \\
\hline
\end{tabular}

Note: Leaching of sulphur least marked on yellow-brown, brown and redbrown soils.

Table 4 summarizes available information on the sulphur requirements of soils in North Auckland. Results of laboratory work by Hogg and by the writer are outlined also.

P HOS P H ATES

Losses of phosphate occur from the main grazing area to stock camps, races, yards and in milk. The rate of this loss depends on type of stock, grazing management and rate of stocking. On a highly-stocked dairy farm, this loss may approach the equivalent of $11 / 2$ cwt superphosphate per acre per annum, and on a sheep farm, 3/4 cwt superphosphate per acre per annum (During, 1967). Yet 3 cwt superphosphate per acre per annum is commonly applied.

Table 5 summarizes some of our estimates on phosphate needs of soils of North Auckland.

P О т A S H

Table 6 gives an estimate of the probable loss of potash by transfer in urine and dung from the main grazing area to stock camps, yards, races, etc., on pastures of different 
TABLE 5: ESTIMATED PHOSPHATE REQUIREMENTS FOR ESTABLISHMENT AND MAINTENANCE OF MEDIUM TO HIGH YIELDING PASTURES

\begin{tabular}{|c|c|c|c|c|c|}
\hline $\begin{array}{l}\text { Parent } \\
\text { Material }\end{array}$ & $\begin{array}{c}\text { Soil } \\
\text { Class }\end{array}$ & $\begin{array}{l}\text { Supe } \\
I^{*}\end{array}$ & $\begin{array}{l}\text { sphate } \\
\mathrm{H}+\end{array}$ & $\begin{array}{r}(c w t / a c) \\
I I I_{+}^{+}\end{array}$ & Comments \\
\hline $\begin{array}{l}\text { Sandstone } \\
\text { Mudstone } \\
\text { Dolerite } \\
\text { Limestone }\end{array}$ & $\bar{A}$ & $3-4 ?$ & $1 \frac{1}{2}-2$ & $1 \mathrm{t}-2$ & $\begin{array}{l}\text { No precise } \\
\text { information. }\end{array}$ \\
\hline $\begin{array}{l}\text { Sandstone } \\
\text { Mudstone } \\
\text { Limestone }\end{array}$ & $B+C$ & $8-10$ & $3-4$ & 2 & \\
\hline $\begin{array}{l}\text { Andesite } \\
\text { Dolerite }\end{array}$ & B - D & $10-12$ & $3-4$ & $2-3$ & \\
\hline $\begin{array}{l}\text { Sandstone } \\
\text { Mudstone } \\
\text { Windblown sand }\end{array}$ & $D-E$ & 6 & $2-3$ & $1-2$ & \\
\hline $\begin{array}{l}\text { Basalt } \\
\text { Basalt } \\
\text { Basalt }\end{array}$ & $\begin{array}{l}A \\
B+C \\
D+E\end{array}$ & $\begin{array}{l}4 ? \\
8-10 \\
10-15\end{array}$ & $\begin{array}{l}2 ? \\
3-4 \\
4-5\end{array}$ & $\begin{array}{l}2 ? \\
3 \\
3\end{array}$ & \\
\hline
\end{tabular}

* I: On virgin soil.

* 11: Maintenance per annum first 10 years or so.

+ III: Maintenance per annum after 10 years or so of regular topdressing. N ote: On some soils of North Auckland the soil test used by the Department of Agriculture to assess phosphate fertility is not satisfactory.

TABLE 6: ESTIMATED LOSS OF POTASH ACCORDING TO STOCK CARRIED AND RECOMMENDED RATES OF TOPDRESSING

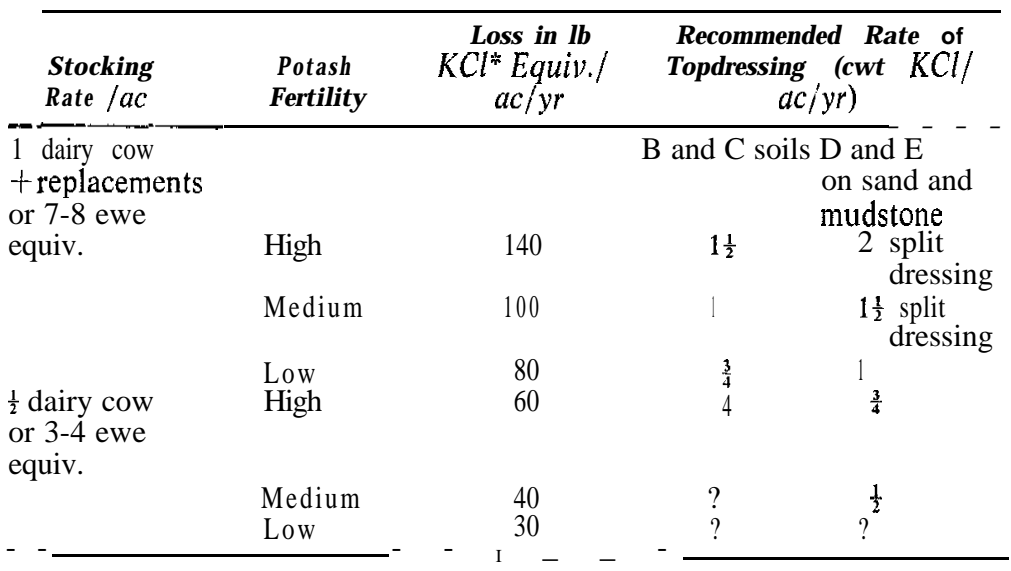

* Muriate of potash.

Nofe: One crop of hay is likely to remove the equivalent of about $1 \mathrm{cwt}$ muriate of potash per acre. 
productivity and potash status. It gives an estimate also of annual requirements for muriate of potash. These estimates are based on rate of potash trials and the assumption that 20 to $25 \%$ of potassium cycled through the grazing animal is lost from the main grazing area.

It is estimated (Metson et al., 1956) that the vast majority of soils of North Auckland other than the A types do not contain large reserves of available potash. On these soils, one to five years of intensive farming are likely to exhaust readily available supplies.

\section{The Balance of Phosphatic and Potassic Fertilizers}

Evidence from our field trial suggests that, on intensivelyfarmed land, the proportion of muriate of potash to superphosphate used must steadily rise. On many gumland soils, 50: 50 and even 40: 60 mixtures of superphosphate-muriate of potash should be used today. There is some evidence that even on the fairly strongly phosphate-fixing ironstone soils derived from basalt, 60:40 mixtures may eventually have a place on intensively-farmed properties.

Table 7 sets out estimates of superphosphate-muriate of potash ratios on several classes of soil.

\section{TABLE 7: ESTIMATEDSUPERPHOSPHATE:MURIATE OF POTASH} RATIO UNDER INTEENSIVE FARMING

\begin{tabular}{|c|c|c|c|}
\hline Soil & $\begin{array}{l}\text { Stock } \\
\text { Carried in } \\
\text { Ewe Equiv. }\end{array}$ & $\% \mathrm{KCl}$ & $\begin{array}{l}\text { Total A mount } \\
\text { Fertilizer/ } \\
a c / y r(c w t)\end{array}$ \\
\hline $\begin{array}{l}\text { High phosphate-fixing } \\
\text { (soils derived from basalt) } \\
\text { C-E soils }\end{array}$ & $\begin{array}{l}3-4 \\
7-8\end{array}$ & $\begin{array}{l}10-15 \\
25-30\end{array}$ & $\begin{array}{l}2 \\
5\end{array}$ \\
\hline $\begin{array}{l}\text { Medium fixing (clay country) } \\
\text { B-C soils }\end{array}$ & $\begin{array}{l}3-4 \\
7-8\end{array}$ & $\begin{array}{l}10-15 \\
40\end{array}$ & $\begin{array}{l}1 \frac{1}{2}-2 \\
3-5\end{array}$ \\
\hline $\begin{array}{l}\text { Low fixing mature gumlands } \\
\text { and }\end{array}$ & 3- 4 & 25 & $1 \frac{1}{2}$ \\
\hline $\begin{array}{l}\text { sandy gumlands } \\
\text { D-E }\end{array}$ & $7-8$ & 50 & 3-4 \\
\hline
\end{tabular}

Note: (1) Seven to eight ewe equivalents can be carried by medium-quality pasture.

(2) Where heavier rates of total application than those stated are used, the percentage of muriate of potash should be reduced. 


\section{CONCLUSION}

According to the most recent records, farmers north of Auckland use $1 \mathrm{cwt}$ of fertilizer for every 1.7 ewe equivalents carried. Fertilizer consumption in this district rose by $45 \%$ from $1961-2$ to $1965-6$ and stock carried by $18 \%$. In determining their topdressing and liming programmes, the North Auckland farmers have a diffcult task. Many properties consist of several soil types with different needs. Farmers must consider not only lime and phosphate, but also potash, molybdenum and sulphur and copper. Mistakes, such as the application of improperly balanced fertilizers or excessive rates of fertilizers in relation to stock carried, are costly and easily made. Also, factors such as management, insects and drainage often lead to inefficient utilization of fertilizer applied. For these reasons, the most effective way of increasing the profitability of fertilizers is to make the maximum use of the professionally-qualified and trained staff employed by various advisory services.

\section{ACKNOW LED GEMENTS}

To H. S. Gibbs and J. McCraw (Soil Bureau) for the loan of colour slides, and D. H. B. McQueen and Miss G. A. Osbaldiston for preparation of slides.

\section{REFERENCES}

Coop, I. E. 1965: N.Z. agric. S'ci. 1: (3) 13-20.

During, C. 1967: Fertilisers and soils in New Zealand farming. N.Z. Dept. of Agric. Bull. No. 409.

Hogg, D. E. 1965: Proc. 27th Conf. N.z. Grassl. Ass., 123-8.

Metson, A. J.; Arbuckle, R. H.; Saunders, Mary L. 1956: Proc. 6th Int. Cong. Soil Sci., B: 619-27.

Taylor, N. H. 1952: Austr. Veterinary J., 28: (7) 183-9.

\section{DISCUSSION}

What is the relative importance of both time-after-initial development, and quantify of topdressing applied, before manuring can be reduced from high levels?

We do not know. It is not feasible to determine this experimentally because there are too many variables. Good soil tests are helpful here. 
Could more details be given on the new soil test for phosphate that was mentioned?

Comment (DR W. M. H. SAUnders) : The Truog phosphate soil test cannot always be interpreted without considerable local experience. Other phosphate tests are being evaluated at present.

How extensive were the data from which the conclusions used in the graphs were reached?

All available trial work from 1926 to 1966 was summarized. Many data are estimates, open to revision.

Is too much phosphate being applied to some pastures?

A large proportion of North Auckland still needs high rates of application. My impression is, however, that in many cases not enough attention is paid to molybdenum, lime and potash so that deficiencies, other than phosphate, limit production. Cases of outright economic waste of phosphate occur here and elsewhere.

Can phosphate requirements be related to age of pasture and previous fertilizer usage?

This cannot be done accurately.

What are Mr During's views on split topdressing instead of the use of elemental sulphur on sandy soils known to lose sulphur rapidly?

This depends on desired pasture vigour. At low stocking rates, one dressing a year using elemental sulphur is usually satisfactory; with high stocking rates, more potassium and phosphate are required. I would recommend topdressing twice a year and then elemental sulphur would not be needed.

N. Wells of Soil Bureau, D.S.I.R., surveyed phosphate levels in white clover on heavily topdressed Jarms. A relatively high proportion did not have high phosphate levels. Would Mr During comment?

Phosphate level in white clover is difficult to interpret. I accept that my recommendations on rates of phosphate do not lead to a high phosphate fertility. However, I am inclined to think that, with good utilization of pasture, high phosphate fertility is essential only at very high levels of stock such as are seldom seen. 